\title{
Speculation Regarding the Posing of Freud in the Group Photograph at the Third International Psychoanalytic Congress
}

\author{
Martin S. Fiebert* \\ Department of Psychology, California State University, Long Beach, 1250 Bellflower Boulevard, Long Beach, CA \\ 90840, USA
}

\begin{abstract}
The third international Psychoanalytic Congress was held at the Erbprinz Hotel in Weimar, Germany on the twenty-first and twenty-second of September of 1911 and was attended by fifty-five individuals, from a number of European countries and America [1] McGuire. Ernest Jones [2], a participant, reports that conference presentations were of a "high order," and the conference itself was "most successful." A key factor contributing to the positive atmosphere was the absence of Alfred Adler and his supporters, who, after a bitter struggle with Freud, had recently withdrawn from the psychoanalytic movement.
\end{abstract}

\section{FREUD AND JUNG}

The acrimonious conflict between Freud and Jung that was to surface in 1912 was clearly not present at Weimar conference. Whatever differences they had been unspoken and Jones [2] described them as being "on the best of terms." Jung had recently written to Freud on the twenty-ninth of August, "I was overjoyed by your letter, being as you know very receptive to any recognition that the father seeks to bestow." [1] Freud, himself, had visited with Jung and his family in Zurich for four days and then traveled with Jung and his wife Emma, to Weimar [1]. During the conference Jones [2] reports that someone complained to Freud regarding the coarseness of Jung's humor and Freud responded, "It's a healthy coarseness." Jung's re-election as president of the International Psychoanalytic Association by acclimation is a clear illustration of the harmony existing between Freud and Jung and their supporters and colleagues.

\section{THE PHOTOGRAPH}

A group photograph [1] was taken of forty-six of the fifty-five conference attendees and revealed the presence of many individuals who later achieved prominence in the psychoanalytic movement, such as Abraham, Brill, Ferenczi, Jones and Rank. A close examination of the photograph [1] reveals that Freud, who was 5'7" tall, is the center of the picture paradoxically towering over Jung on his left whose height was 6'2" [3]. It is clear that Jung is bending over while Freud, most likely, is standing on a stool or box.

While there is no direct evidence as to the origins of this arrangement, I strongly suspect that Jung organized the posing of the photograph. I would guess that the photograph, as is most often the case, was taken at the end of the congress. At this point Jung, who had been unanimously confirmed as

*Address correspondence to this author at the Department of Psychology, California State University, Long Beach, 1250 Bellflower Boulevard, Long Beach, CA 90840, USA; E-mail: mfiebert@CSULB.edu
President, would most likely has a major voice regarding the placement of individuals in the photograph.

I suspect that Jung, at his own moment of triumph, was eager to share the glory and good feeling with his mentor and "surrogate" father by arranging Freud's placement in the center of the picture. In addition to elevating Freud's physical stature, Jung exaggerated Freud's physical presence, and symbolically his importance, by dramatically stooping over. Such a gesture on Jung's part is clearly in keeping with Lou Andreas-Salome's [4] eyewitness report of Jung displaying at the conference "a kind of robust gaiety and exuberant vitality." As pictured Jung's somewhat flamboyant neckwear is consistent with this attitude.

Assuming that Jung had primary responsibility for the posing of the photograph let me speculate regarding Freud's response to this situation. Freud was generally uneasy about being photographed. For example, in his response to Jung's request for his picture in 1907 he wrote, "In the last fifteen years I have never willingly sat for a photographer, because I am too vain to countenance my physical deterioration." In addition, Roazen [3] learned in an unpublished interview with Reik that Freud was particularly uncomfortable about his height relative to Jung's. Therefore, it seems to me that Freud was somewhat uneasy during the photograph arrangement but, my guess is that he approved and was generally pleased at his artificially elevated placement in the center of the group, and was probably appreciative of Jung's efforts.

Finally, there is a most interesting and telling epilogue to this event. Jones, in an unpublished letter to Freud in 1926, reveals that at the end of the conference Jung told him that "someday he would stand higher than Freud." Jones recalls that he was shocked at this statement and asked Jung why he didn't analyze his father complex [5].

\section{SUMMARY}

Author suggests that Jung was instrumental in the posing of Freud in the group photograph taken at the third interna- 


\section{The Weimar Congress, 1911}
1 O. Rank
2 L. Binswanger
3 E. Bleuler
4 M. Moltzer
5 O. Pfister
6 A. A. Bril
7 A. Maeder
8 S. Ferenczi
9 L. Andreas-Salome
$10 \mathrm{~S}$. Freud
11 C. G.Jung
12 E. Jung
13 K. Abraham
14 A. Wolff
15 J. Putnam
16 E. Jones
17 F. Riklin
18 W. Stekel

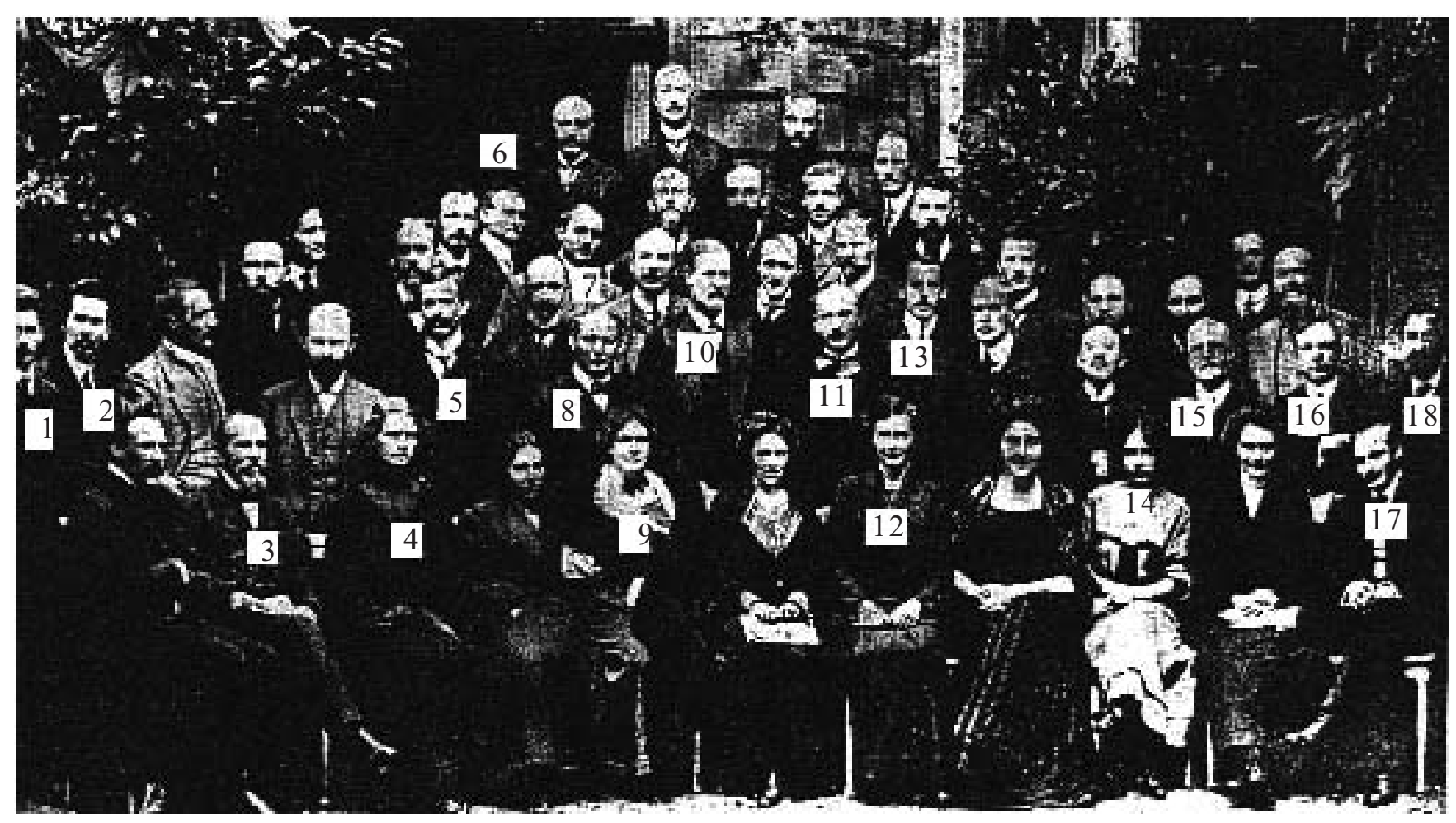

Fig. (1). Photograph of participants at Psychoanalysitic Congress.

tional Psychoanalytic Congress in Weimar. Speculation regarding factors that may have influenced Jung's decision and Freud's reaction are presented.

\section{AUTHOR NOTE}

A earlier version of this paper was presented at the annual meeting of the American Psychological Society Convention in Washington, D.C., July, 1994.

\section{REFERENCES}

[1] McGuire W, Ed. The Freud/Jung Letters: The Correspondence between Sigmund Freud and C.G. Jung. Cambridge, MA: Harvard University Press 1988

[2] Jones E. The Life and Work of Sigmund Freud. Years of Maturity. New York: Basic Books 1955; vol. II.

[3] Roazen P. Freud and His Followers. New York: Knopf 1975.

[4] Andreas-Salome L. The Freud Journal of Lou Andreas-Salome. New York: Basic Books 1964.

[5] Donn L. Freud and Jung. Years of Friendship, Years of Loss. New York: Collier 1988. 